\title{
Hydrothermal Alteration of Basaltic Rocks at Eruptive Vents on Mount Cameroon Volcano, West Africa
}

\author{
Akumbom Vishiti ${ }^{*}$, Taboko Armstrong2, Elisha Mutum Shemang3, \\ Jacques Etame1,4, Cheo Emmanuel Suh ${ }^{2,5}$ \\ ${ }^{1}$ Department of Civil Engineering, The University Institute of Technology (IUT), University of Douala, \\ Douala, Cameroon \\ ${ }^{2}$ Economic Geology Unit, Department of Geology, University of Buea, Buea, Cameroon \\ ${ }^{3}$ Department of Earth and Environmental Science, Botswana International University of Science and Technology, \\ Palapye, Botswana \\ ${ }^{4}$ Laboratory of Geosciences Natural Resources and Environment, Department of Earth Science, University of Douala, \\ Douala, Cameroon \\ ${ }^{5}$ Department of Geology, Mining and Environmental Science, The University of Bamenda, Bambili, Cameroon \\ Email: *vakumbom@gmail.com
}

How to cite this paper: Vishiti, A., Armstrong, T., Shemang, E.M., Etame, J. and Suh, C.E. (2018) Hydrothermal Alteration of Basaltic Rocks at Eruptive Vents on Mount Cameroon Volcano, West Africa. International Journal of Geosciences, 9 , 513-527.

https://doi.org/10.4236/ijg.2018.99030

Received: August 15, 2018

Accepted: September 10, 2018

Published: September 13, 2018

Copyright (c) 2018 by authors and Scientific Research Publishing Inc. This work is licensed under the Creative Commons Attribution International License (CC BY 4.0)

http://creativecommons.org/licenses/by/4.0/

\section{cc) (i) Open Access}

\begin{abstract}
The study of changes in rocks due to interaction with hydrothermal fluids at active volcanoes provides insights into wall rock alteration associated with ore deposits formed in the geological past. Therefore, the nature of mineral alteration and chemical changes experienced by wall rocks can be investigated at eruptive sites on active volcanoes and the results used to better constrain ore-forming processes. In this study, we investigated the alteration at eruptive sites at Mount Cameroon volcano. These eruptive vents lie along NE-SW-trending fissures that define the Mount Cameroon rift. The vents are surrounded by cones composed largely of pyroclastic materials and to a lesser extent lava. Fumaroles (volcanic gases) rising through the vents during and after the 1999 eruption have resulted in the alteration of the pyroclastic robble along the fissures and the inner walls of the cones. Consequently, altered basaltic materials are covered with thin films of reddish, yellowish to whitish secondary minerals. These coatings result from an interaction between the surfaces of the basaltic glass with volcanically-derived acidic fluids. Petrographic investigations and XRD analysis of the basalts have identified primary mineral phases, such as olivine, pyroxene (mainly augite) and feldspars. Alteration products revealed include ubiquitous silica as well as gypsum, magnetite, feldspar, alunite and jarosite. Jarosite occurrence indicates that $\mathrm{SO}_{2}$ is the primary volcanically-derived acid source involved in coating for-
\end{abstract}


mation. High contents of sulfur identified in the basalts indicate that melts at Mount Cameroon can be sulfur saturated as backed by previous melt inclusion data. Whole rock geochemical analysis shows a gain in silica in the altered samples and this ties with the mass balance calculations although minor gains of $\mathrm{Al}_{2} \mathrm{O}_{3}, \mathrm{Fe}_{2} \mathrm{O}_{3}^{\mathrm{T}}, \mathrm{MgO}, \mathrm{MnO}, \mathrm{CaO}$ and $\mathrm{K}_{2} \mathrm{O}$ are shown by some samples.

\section{Keywords}

Mount Cameroon, 1999 Eruption, Fumarole, Wall Rock Alteration, Mass

Balance

\section{Introduction}

Mount Cameroon is an active volcano with an intraplate setting on the African continent. It last erupted in 2000 and although the eruption behavior, petrochemistry of eruption products [1]-[8], associated risk and community perceptions [9]-[14] have been studied; the fumarolic activity and attendant wall rock alteration at the eruptive sites have witnessed less profound scientific investigation. Such investigations are important considering that hydrothermal activities at active volcanoes provide proxies for a better understanding of such processes in the geological past and how they led to the formation of ore deposits. Hydrothermal systems have been reported in a wide variety of settings: mid-ocean ridges (black smokers), subduction zones and continental settings. Hydrothermal processes result in changes in the affected rocks that can be recognized as textural, color, mineralogical and chemical mass loss or gain for various elements [15] [16] [17] [18]. Fumaroles are known to be sites for passage of fluids and degassing leading to wall rock alteration [19]. Studying recent volcanoes to compare and contrast modern and ancient systems is not only important in the field of volcanology, but also in ore mineralogy as it provides an insight to ore forming processes. Also the results of such studies provide the basis for distinguishing changes in rocks due to weathering (supergene alteration) and those directly linked to hypogene processes, such as hydrothermal activity. In this study, we describe the recent 1999 eruptive vents at Mount Cameroon volcano and the alteration recognized around these vents due to fumarole activity. We further identify the principal alteration minerals and precipitate phases by the XRD method and compute element dispersion between the fresh basalt and the hydrothermally altered varieties using the mass balance technique [20].

\section{Geological Context of Mount Cameroon and the 1999 Eruption}

Mount Cameroon in southwest Cameroon (Figure 1(a)) is one of Africa's most active volcanoes and constitutes a major volcanic edifice at the transition between the oceanic and the continental sectors of the Cameroon Volcanic Line 


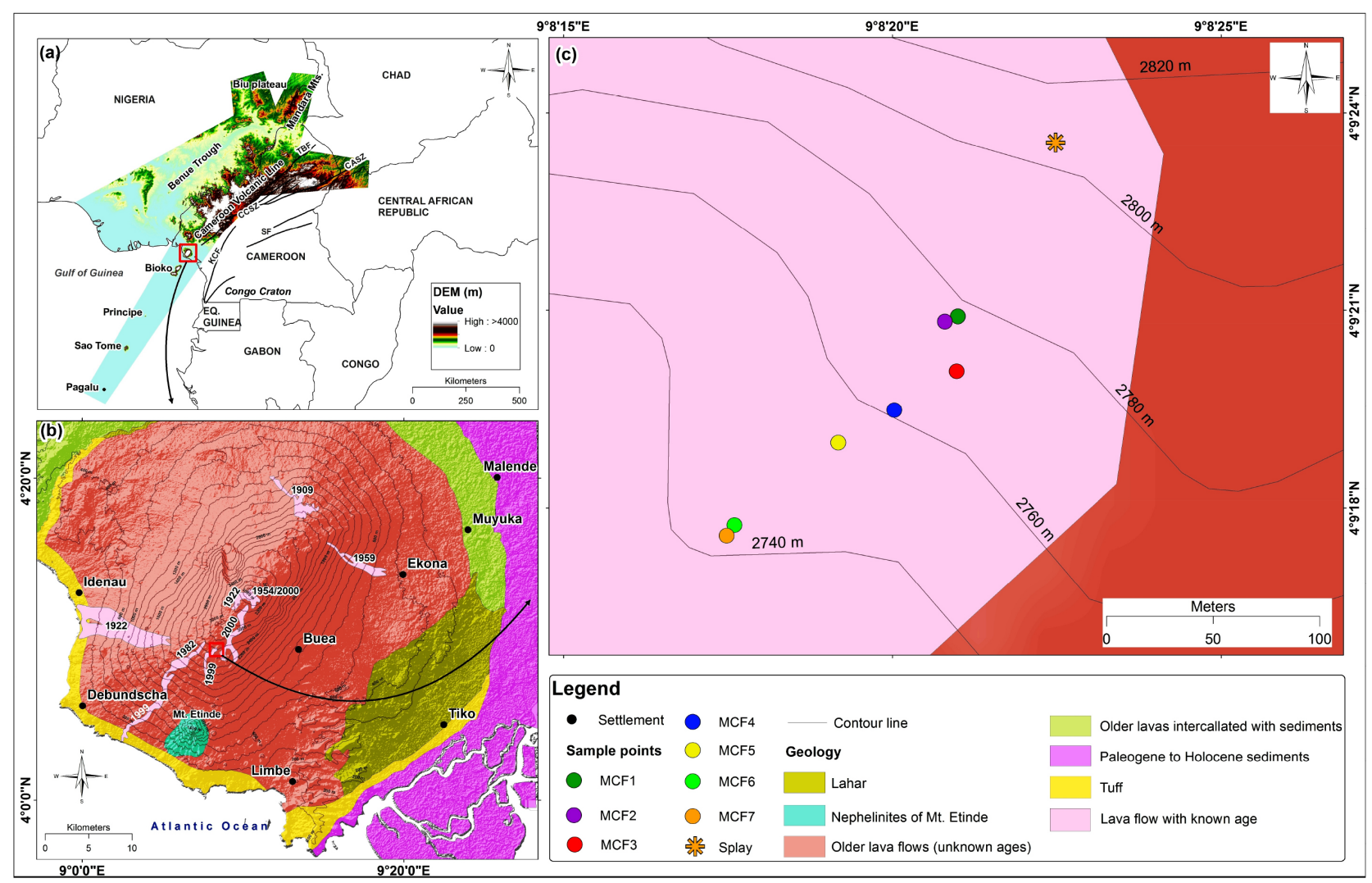

Figure 1. (a) Sketch map of the Cameroon Volcanic Line (CVL) showing the location of Mount Cameroon along the NE-SW-trending volcanic chain. (b) Contoured map of Mount Cameroon displaying the $20^{\text {th }}$ century eruption sites and lava flows (after [2]). (c) Sample location points along the 1999 eruptive fissure on Mount Cameroon.

(CVL). The near $1700 \mathrm{~km}$ long CVL is an African intraplate 'fan-shaped' alkaline volcano-plutonic rift zone of variable width $(<200 \mathrm{~km})$, with a $\sim 66 \mathrm{Ma}$ history of magmatic activity without any systematic internal pattern of age variation [7]. Mount Cameroon rises steeply to $4095 \mathrm{~m}$ and its last eight eruptions have been well documented (Figure 1(b)), namely the 1909, 1922, 1954, 1959, 1982, 1989, 1999 and 2000 eruptions [3] [8] [14] [21]. The Mount Cameroon edifice is built on a sedimentary substratum and is dominantly covered by basanite, andesitic and hawaiite lavas and subsidiary tephra deposits that reveal a variation in texture [2] [3] [4]. According to [1] [2] [5] [6] [10] [14] [22], the most critical recent eruptions of Mount Cameroon occurred between 28 March and 22 April 1999 and 28 May and 7 June 2000. The 2000 eruption may have been a continuation of the 1999 event [2] in part as reflected in the heightened and sustained seismic activities during the period separating these eruptions. Mount Cameroon is characterized by effusion of lava and associated weak Strombolian activity [2]. The volcanic activity of this edifice results in earthquakes, lengthy lava flows, tephra fall and volcanic degassing [14] [21]. According to [2] [4] [5], the 1999 lavas are basanites with occasional hawaiites. The lava is porphyritic with olivine, clinopyroxene, plagioclase and titanomagnetite phenocrysts set in a fine-grained often partially glassy groundmass [2] [6]. 


\section{Material and Methods}

\subsection{Field Protocol}

Vents with fumaroles on the 1999 eruptive fissures (Figure 1(c)) were mapped diligently and representative sample collected. Basaltic rocks bearing precipitates were sampled around the eruptive vents and a preliminary mineral identification done using the hand lens. The structural configuration of various fissures and splays were measured. Both the fresh and hydrothermally altered basaltic rocks sampled were split into two parts. While a section of the sample was used for thin section preparation the remaining samples were pulverized for X-ray diffraction (XRD) and X-ray Fluorescence (XRF) analysis.

\subsection{Petrography and XRD Investigations}

Thin sections were prepared following standard procedures at the Institut de Recherche Geologigue et Miniere (IRGM), Nkolbison Yaoundé (Cameroon) and studied using transmitted and reflected light microscopy at the Department of Geology, University of Buea. The presence of major minerals where determined semi-quantitatively on the bulk fraction using PW1710X-ray diffractometer with automatic divergence slit and monochromatic $\operatorname{CoK} \alpha$ radiation at the University of Botswana, Gaborone. Powder from each sample was mounted with a random orientation in an aluminum sample holder. Instrumental conditions were as follows: $40 \mathrm{kv}, 35 \mathrm{nA}$, goniometerscan from $5^{\circ}$ to $70^{\circ} 2 \theta$ for bulk samples, step size $=0.02^{\circ}$, scan speed $=1.2^{\circ} / \mathrm{min}$ and count time $=0.5 \mathrm{~s}$. An interactive software package (MacDiff, freeware from http://www.geolpal.uni-franfurt.de/Staff/Homepages/Petschick/classisoftware.ht ml) was used to identify the minerals. Identifications are based on multiple peak matches using the mineral data base provided with MacDiff.

\subsection{Chemical Analysis and Element Mobility}

A portion of each sample was crushed in an alumina plate jaw crusher and then pulverized in a shatter box with an alumina container and puck. These powders were analyzed for major elements by X-ray Fluorescence (XRF) at Actlabs in Canada. Loss on ignition was determined by weight difference after ignition at $1000^{\circ} \mathrm{C}$. The element dispersion between the fresh basalts and the hydrothermally altered varieties were then computed using the mass balance method of [20] with $\mathrm{TiO}_{2}$ as the least mobile element of choice. The mass change for a given element in an altered rock is calculated using the following equation:

$$
\Delta C_{\mathrm{TiO}_{2} . J}=100 *\left[\left(C_{J . A} / C_{J . F}\right) /\left(C_{\mathrm{TiO}_{2} . A} / C_{\mathrm{TiO}_{2} . F}\right)\right]-1
$$

where $C_{J \mathrm{~A}}$ is the concentration of the element in the altered rock, $C_{J . F}$ is the concentration of the element in the fresh/parent rock. The composition of the parent rock (fresh basalt) was used as a reference for the mass balance calculation. 


\section{Results}

\subsection{Alteration around Vents}

Vent- and fissure-controlled active fumaroles sites observed along the 1999 fissures at Mount Cameron volcano are semi-circular to circular in shape (Figure 2(a), Figure 2(f), Figure 2(h)). They lie along NE-SW-trending deformational fissures that define the general trend of the Mount Cameroon rift. The fissures range in width from $0.5 \mathrm{~m}-1 \mathrm{~m}$ (Figure 2(e), Figure 2(g)). Some of the fissures occur as splays characterized by low rate degassing. The walls of the vents are covered with coatings of various thicknesses and colors (Figures 2 (b)-(d)). The altered rocks vary from reddish-whitish to yellowish in color (Figure 2(d)). Some are covered with thin silica films with typical lava drain features (Figure 2(d)) reminiscent of repeated lava flux in the conduit and prolonged fumarolic alteration.

The main petrographic features of the fresh basalts and their altered counterparts are presented in Figure 3. The rocks are coarse-grained and porphyritic with dominant phenocryst phases being olivine and clinopyroxene (Figure 3(a), Figure 3(c), Figure 3(e), Figure 3(h)) while plagioclase is common in the microlite-laden groundmass (Figure 3(b), Figure 3(d), Figure 3(f), Figure 3(g)). Some of the olivine phenocrysts show fracture-controlled alteration (Figure 3(a), Figure 3(c), Figure 3(e), Figure 3(h)). The phenocrysts are usually euhedral to anhedral, amoeboidal and skeletal in shape. Intergrowth textures are common (Figure 3(b)) with recognizable simple and polysynthetic twins in augite and anorthite, respectively (Figure 3(b), Figure 3(d), Figure 3(f), Figure $3(\mathrm{~g}))$. Reaction textures are also common and include sieve-textured cores in olivine, serrated core-rim boundaries in clinopyroxene and cleavage-controlled coloration and alteration seams. The alteration phases are resolvable only by $\mathrm{XRD}$ as the material is often amorphous.

\subsection{Mineral Identification and Whole Rock Geochemistry}

The primary and secondary minerals identified by XRD are presented in Figure 4. The dominant mineral coating on the altered rocks is sulfur (octa-sulfur, native sulfur and s-brimstone). The other alteration products include silica, feldspar (albite), gypsum, magnetite, jarosite and alunite while relicts of primary minerals phase such as augite and olivine are still noticeable (Figure 4).

The geochemical composition of both fresh and altered basaltic rocks is presented in Table 1. Compared to the fresh basalt, the altered products have elevated concentrations of $\mathrm{SiO}_{2}$ but show significant depletion in $\mathrm{Al}_{2} \mathrm{O}_{3}$ (avg. = 4.8), $\mathrm{Fe}_{2} \mathrm{O}_{3}{ }^{\mathrm{T}}$ (avg. = 4.6), $\mathrm{MgO}$ (avg. = 2.4), $\mathrm{CaO}$ (avg. = 3.6) and $\mathrm{Na}_{2} \mathrm{O}$ (avg. = 0.8). It is remarkable that the altered samples have high loss on ignition values since the precipitates are essentially water-bearing or hydrous phases. On the gain and loss plot (Figure 5), the altered basalts show a significant gain in $\mathrm{SiO}_{2}$ while most of the other major elements are depleted. Exceptionally, $\mathrm{Al}_{2} \mathrm{O}_{3}, \mathrm{Fe}_{2} \mathrm{O}_{3}^{\mathrm{T}}, \mathrm{MnO}$, $\mathrm{MgO}, \mathrm{CaO}$ and $\mathrm{K}_{2} \mathrm{O}$ also show an increase (Figure 5) in some samples. 

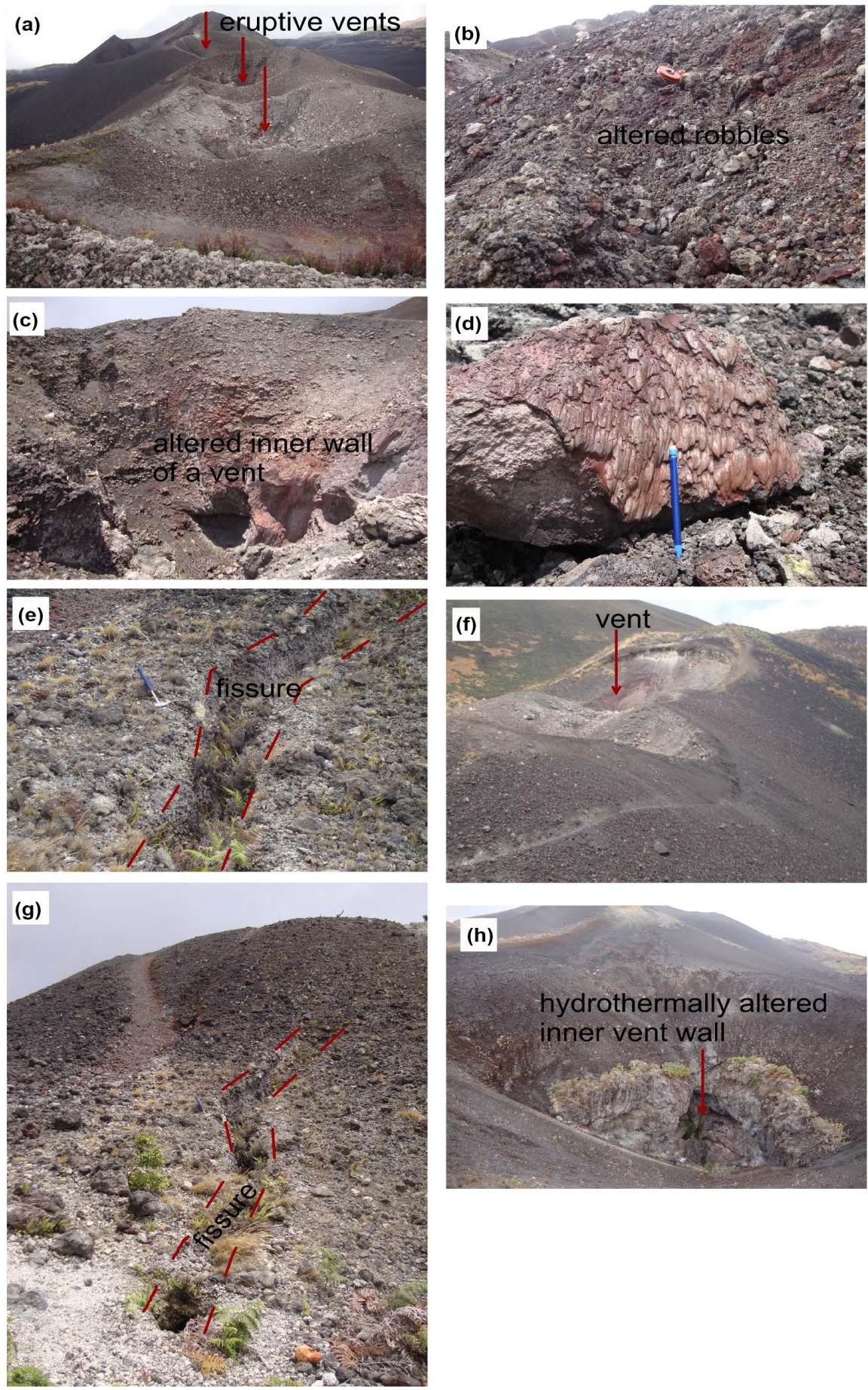

Figure 2. Characteristic hydrothermal alteration features of the 1999 eruptive vents. (a) Aligned cones around the 1999 eruptive vents. Note that the inner walls of some vents are reddish to whitish/yellowish due to hydrothermal alteration by fumaroles (volcanic gases). (b) Different types of altered robbles on the inner wall of a cone. (c) Vent with reddish wall due to alteration. (d) Rock piece sampled from the inner wall of the cone in (c). Here, a reddish, altered, polished thin coating of oxidized siliceous material with lava drain structures mantles a dark unaltered basaltic core. (e) NE-SW running fissures that control cone alignment and serve as passage ways for rising fumaroles. (f) Alteration around walls of vents. (g) Fissure running NE-SW. (h) Alteration along the walls of vents. 

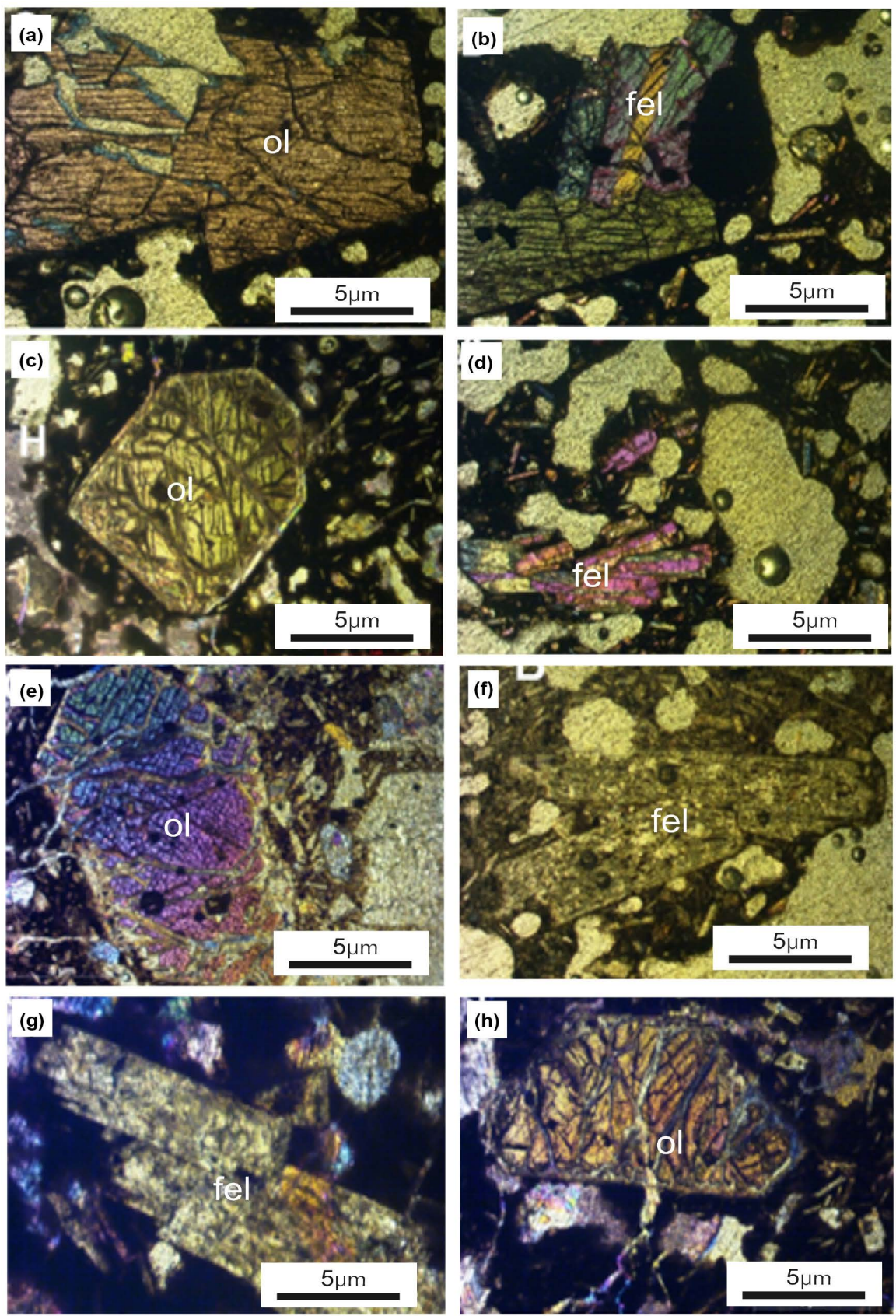

Figure 3. Representative photomicrographs of altered basaltic rocks from the Mount Cameroon 1999 eruptive vents (a) Olivine crystal defined by fracture-controlled alteration. (b) Intergrowth of feldspar with olivine. Notice the simple twin in feldspars. (c) (e) (h) Fractured olivine with hydrothermally altered rims and cores. (d) (f) (g) Laths of plagioclase feldspar defining weak magmatic (flow) alignment. $\mathrm{Ol}=$ olivine, fel = feldspar.

\section{Interpretation and Discussion}

\subsection{Development of Alteration Products at Active Volcanoes}

At active volcanoes, magmatic gases tend to interact with surrounding wall rock materials and pre-existing hydrothermal systems thereby greatly modifying the composition of the fluids, the residual gas and the wall rock [23]. Basaltic rocks 

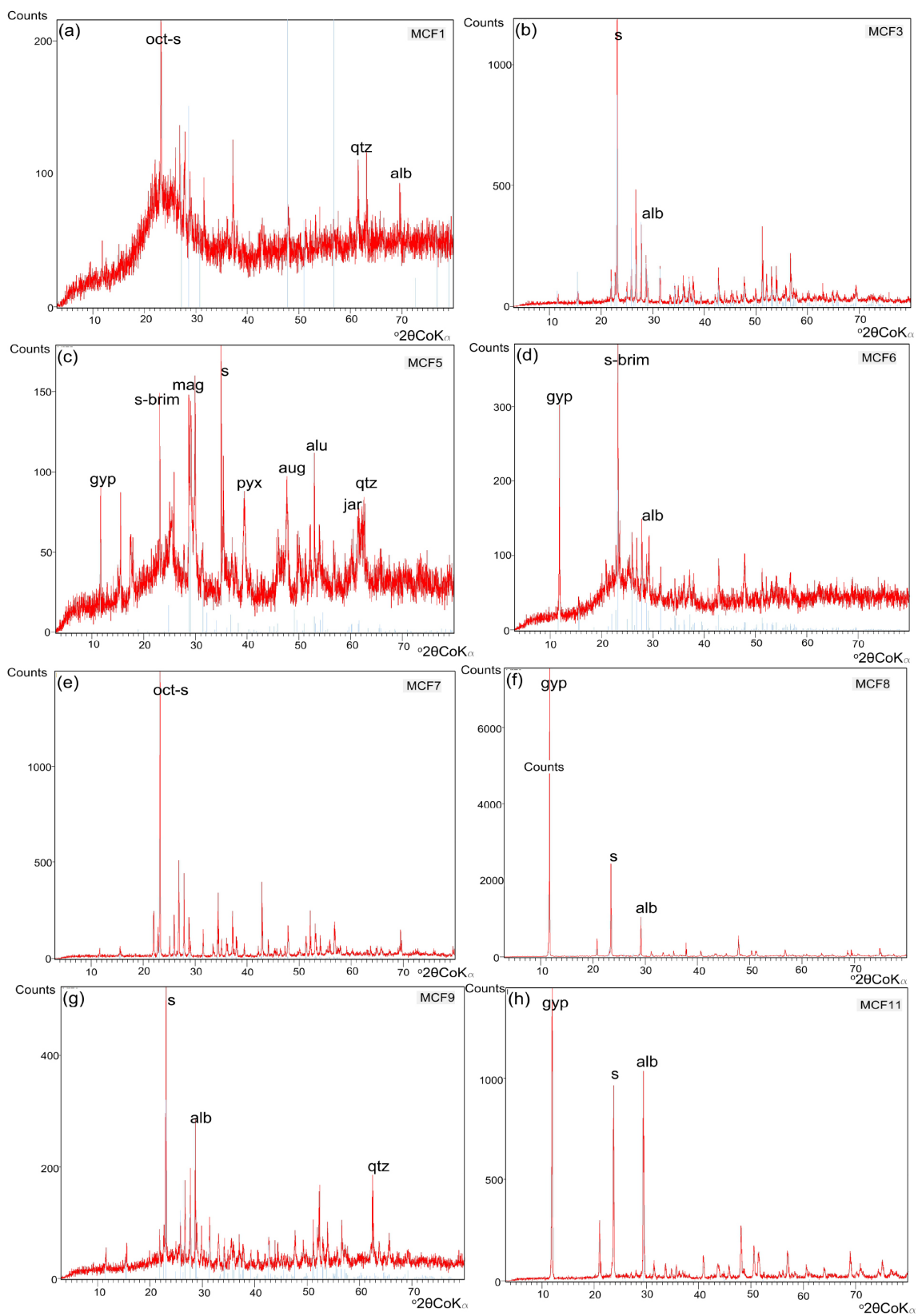

Figure 4. Representative XRD patterns of altered basaltic rocks from the 1999 vents, Mount Cameroon volcano. (a) Sulfur coating occurring in the form of octa-sulfur. Alteration products here include silica and albite. (b) Sulfur and albite alteration. (c) (d) Gypsum, sulfur, magnetite, alunite, pyroxene, augite, jarosite and silica. (e)-(h). Sulfur, gypsum, albite and silica alteration. Abbreviations alb = albite, $s=$ sulfur, octa-s = octasulfur, $\mathrm{s}$-brim = sulfur brimstone, $\mathrm{qtz}=$ siliceous material, gyp = gypsum, alu = alunite, aug $=$ augite, $\operatorname{mag}=$ magnetite, $\operatorname{pyx}=$ pyroxene,$j a r=$ jarosite.

from the 1999 eruptive vents at Mount Cameroon volcano are hydrothermally altered and coated with oxidized siliceous material as well as sulfur-rich amorphous phases (Figures 2-4). This coating developed as a result of the chemical interaction between the rock substrate (basaltic glass and primary minerals) and fluids in its environment [24] [25]. Although this chemical 
Table 1. Major element (wt\%) composition of fresh and hydrothermally altered basalts from the 1999 eruptive vents on Mount Cameroon volcano. Sample collection sites are shown in Figure 1.

\begin{tabular}{|c|c|c|c|c|c|c|c|c|c|c|c|c|}
\hline \multirow{3}{*}{ Major elements } & \multicolumn{12}{|c|}{ Basaltic rocks } \\
\hline & \multicolumn{3}{|c|}{ Fresh } & \multicolumn{8}{|c|}{ Hydrothermally altered } & \multirow[b]{2}{*}{ MCF7 } \\
\hline & DL & & MCF5 & MCF9 & MCF8 & MCF6 & MCF1 & MCF4 & MCF2 & MCF3 & MCF10 & \\
\hline \multicolumn{13}{|l|}{ XRF (wt.\%) } \\
\hline $\mathrm{SiO}_{2}$ & 0.02 & 45.99 & 59.82 & 70.01 & 45.98 & 79.99 & 73.75 & 73.6 & 81.33 & 79.52 & 54.99 & 59.08 \\
\hline $\mathrm{TiO}_{2}$ & 0.001 & 3.25 & 1.32 & 1.69 & 3.24 & 0.57 & 1.62 & 1.55 & 0.55 & 0.57 & 2.33 & 1.36 \\
\hline $\mathrm{Al}_{2} \mathrm{O}_{3}$ & 0.01 & 15.02 & 6.22 & 7.61 & 15.05 & 0.22 & 2.14 & 3.14 & 0.14 & 0.13 & 7.01 & 5.91 \\
\hline $\mathrm{Fe}_{2} \mathrm{O}_{3}^{\mathrm{T}}$ & 0.01 & 11.85 & 6.04 & 7.34 & 11.88 & 0.49 & 3.56 & 2.76 & 0.71 & 0.69 & 5.94 & 6.14 \\
\hline $\mathrm{MnO}$ & 0.001 & 0.2 & 0.07 & 0.1 & 0.2 & 0.1 & 0.1 & 0.2 & 0.02 & 0.02 & 0.01 & 0.01 \\
\hline $\mathrm{MgO}$ & 0.01 & 6.91 & 3.01 & 3.16 & 6.92 & 0.11 & 0.13 & 0.11 & 0.07 & 0.06 & 4.11 & 5.91 \\
\hline $\mathrm{CaO}$ & 0.01 & 11.11 & 4.67 & 5.69 & 11.12 & 0.46 & 0.39 & 0.41 & 0.33 & 0.39 & 5.49 & 6.78 \\
\hline $\mathrm{Na}_{2} \mathrm{O}$ & 0.01 & 3.71 & 0.63 & 0.77 & 3.7 & 0.28 & 0.18 & 0.17 & 0.11 & 0.16 & 0.73 & 0.94 \\
\hline $\mathrm{K}_{2} \mathrm{O}$ & 0.01 & 1.44 & 0.43 & 0.34 & 1.46 & 0.77 & 0.28 & 0.29 & 0.1 & 0.1 & 0.53 & 1.31 \\
\hline $\mathrm{P}_{2} \mathrm{O}_{5}$ & 0.001 & 0.65 & 0.88 & 0.09 & 0.66 & 0.08 & 0.08 & 0.09 & 0.03 & 0.05 & 0.07 & 0.1 \\
\hline LOI & 0.1 & -0.33 & 17.7 & 3.05 & -0.35 & 16.91 & 17.61 & 17.6 & 16.51 & 17.96 & 18.7 & 12.21 \\
\hline Total & & 99.8 & 99.99 & 99.85 & 99.86 & 99.98 & 99.84 & 99.92 & 99.9 & 99.65 & 99.91 & 99.75 \\
\hline
\end{tabular}

$\mathrm{DL}=$ Detection Limit.

interaction may involve external deposition from silica-saturated fluids [18] [26], in this study microtextural evidence such as reaction rims of mineral grains suggests that the silica coating formed by in situ dissolution and re-precipitation of silica mobilized in solution as noted previously by [27]. The textural characteristics of coatings formed in this study reveal an interaction with acidic fluids and vapor. A potential source of acidity for alteration of the basaltic surfaces at active volcanoes is volatile degassing of the magma before, during and after an eruption. The high sulfur content of the altered basalts at Mount Cameroon (Figure 4) indicates that $\mathrm{SO}_{2}$ is the principal acid source involved in coating formation at the 1999 eruptive vents. According to [5], the most primitive glass inclusions from this volcanic edifice are volatile-rich with 1.7 wt.\% $\mathrm{H}_{2} \mathrm{O}, 967$ ppm $\mathrm{CO}_{2}, 1530 \mathrm{ppm} \mathrm{F}, 2400 \mathrm{ppm} \mathrm{S}$, and $1270 \mathrm{ppm} \mathrm{Cl}$; with the $\mathrm{F}$ content being the highest known for basaltic glasses. These gases, once dissolved in shallow ground water produce acidic solutions capable of altering the primary minerals in the basaltic rocks. The melts upon experiencing fractional crystallization became S-saturated resulting in extensive S outgassing and the precipitation of native sulfur. This is supported by a continuous degassing of sulfur from the eruptive vents. High sulfur contents and tiny spherical sulphide grains in glass inclusions from the Mount Cameroon volcano is reported in [5]; further evidence of S-rich melts at this edifice.

Replacement reactions in the basaltic rocks resulted in the formation of various secondary minerals. The breakdown of pyroxene and calcic plagioclase resulted in the liberation of silica and calcium. While the siliceous material is 

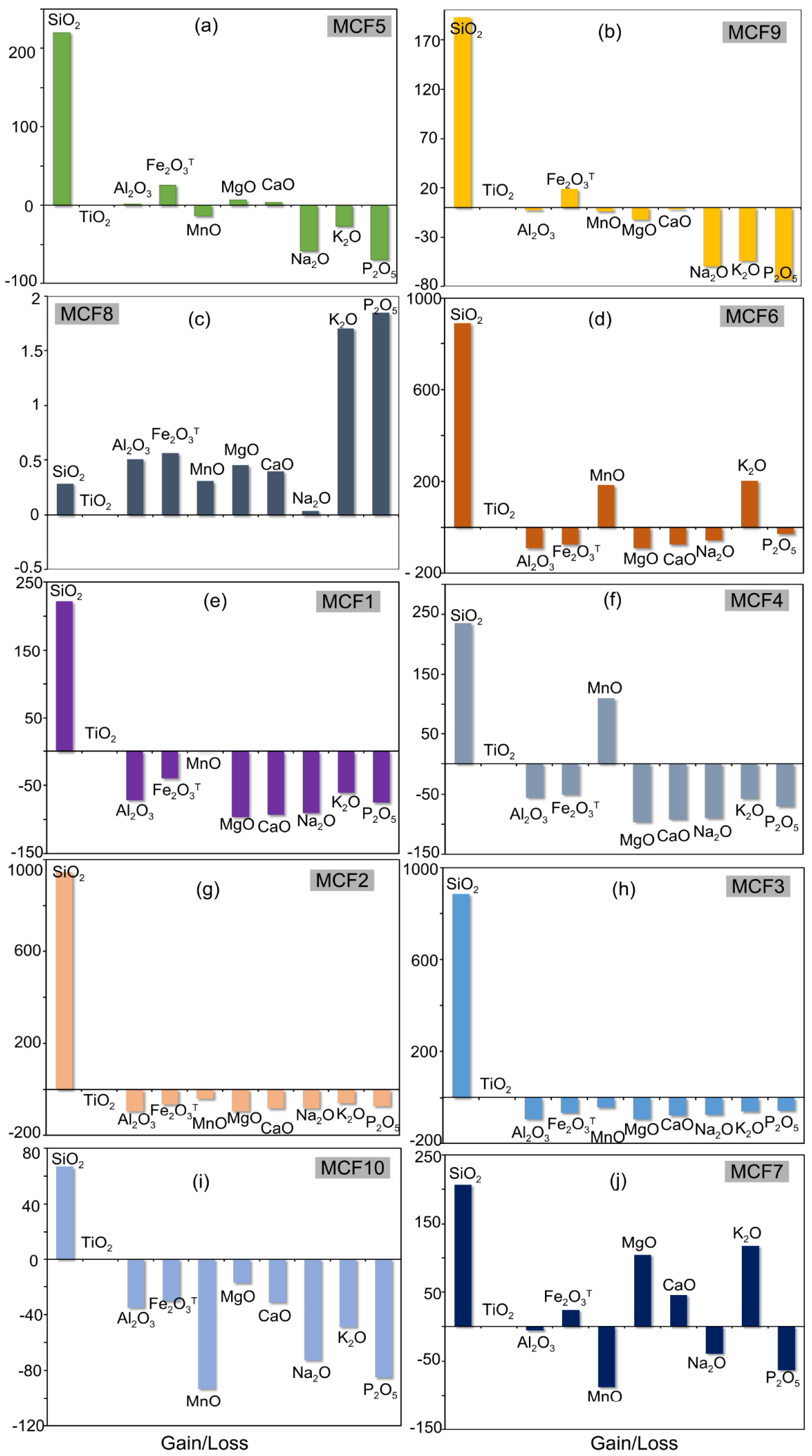

Figure 5. Mass balance calculation data of altered basaltic rocks from the 1999 Mount Cameroon eruption displayed as loss and gain diagrams (a)-(j). The basaltic rocks are characterized by a gain in silica although some samples are typified by a gain in $\mathrm{Al}_{2} \mathrm{O}_{3}$, $\mathrm{Fe}_{2} \mathrm{O}_{3}^{\mathrm{T}}, \mathrm{MnO}, \mathrm{MgO}, \mathrm{CaO}$ and $\mathrm{K}_{2} \mathrm{O}$. 
progressively reddened by iron possibly derived from the breakdown of fayalitic olivine, the calcium is consumed in the formation of gypsum. Indeed ancient hydrothermal ore deposits that are rich in silica and iron also form by replacement reactions within silicious rocks at low temperatures [28] similar to the temperature expected at these 1999 vents. The occurrence of silica in the altered samples reflects cations depletion by acid leaching. Reddish to brownish Fe-oxyhydroxide coatings observed on the Mount Cameroon vent wall samples have been reported from mid ocean ridge basalts that have undergone acidic fluids-driven hydrothermal alteration due to the replacement of plagioclase, olivine and basaltic glass [29]. We show in this study that these processes although better documented at oceanic settings also occur on land. At oceanic settings, diffuse hydrothermal fluid flow is observed from cracks and crevices in the basaltic seafloor. At Mt Cameroon the fluids follow fissures and vents pointing to the similarity of both marine and continental volcanic degassing.

Alunite and jarosite as alteration minerals in numerous ore deposits represent advanced argillic alteration [30]. The presence of these phases in altered rocks at Mount Cameroon emphasizes the role of acidic hydrothermal fluids in the formation of such deposits. Alunite typifies S-saturated systems which upon oxidation develop sulfate-bearing phases. The presence of jarosite also supports the fact that a primary volcanically-derived source of acid is involved in the formation of the precipitates which occur as coatings [31]. Sodium mobilized from the breakdown of primary phases is used up in the formation of albite detected by the XRD technique. The occurrence of albite within this volcanic edifice points to a sodic alteration and generally, albite commonly replaces plagioclase in pervasively altered igneous rocks (e.g. [32]).

\subsection{Element Remobilization during Hydrothermal Alteration}

The changes in the mineralogy of the altered basaltic rocks as described above are also reflected in their whole rock geochemistry. In fact the mass balance calculations have identified high contents of $\mathrm{SiO}_{2}, \mathrm{Fe}_{2} \mathrm{O}_{3}^{\mathrm{T}}, \mathrm{Al}_{2} \mathrm{O}_{3}, \mathrm{MnO}, \mathrm{CaO}$ and $\mathrm{K}_{2} \mathrm{O}$ in some samples when compared to the fresh unaltered basalt. According to [18], thin films of water acidified by contact with volcanic vapor can dissolve near surface basalts then precipitate amorphous silica. This results in high $\mathrm{SiO}_{2}$ content in such samples. The sulfur dioxide emanating from the vents and fissures react with fluids such as rain water to form weak sulfuric acid which then attacks the surface of the basaltic rocks reacting with the cations and leaching them out from the system. Such remobilized cations constitute the main elements in the new mineral phases in the altered rocks, thus they have enrichments in these cations over the fresh basalt. The high loss on ignition values of the altered basalts as compared to the fresh basalt concords with the development of hydrated mineral phases through various cation-driven reactions.

\section{Conclusions}

The following conclusions can be drawn from this study: 
1) The 1999 eruptive vents at Mount Cameroon are aligned along NE-SW-trending fissure that served as pathways for the flow of hydrothermal fluids from magmatic degassing.

2) Basaltic rocks sampled from this vent are hydrothermally altered and are coated with sulfur, Fe-oxyhydroxides and siliceous material. The coating developed as a result of a chemical interaction between the basaltic glass and volcanically acidified fluid as observed at mid ocean ridges.

3) Alteration products identified include: silica, feldspar, gypsum, alunite, magnetite and jarosite. These alteration minerals are similar to an advance argillic alteration in ancient mineral deposits.

4) The whole rock geochemistry reveals high silica content in the altered basalts. Silicification is matched with the development of gypsum (Ca enrichment), alunite (elevated $\mathrm{Na}$ ), oxyhydroxides (Fe enrichment). This is reflected in the mass balance calculations and confirms the dissolution of the near surface basaltic glasses and primary mineral phases by acidified volcanic vapor. The remobilized soluble cations are then taken up in formation and the precipitation of the various amorphous secondary mineral phases. These results are significant because they show conclusively that this alteration mineral assemblage developed purely through hydrothermal alteration and it is not weathering-related. Identifying a similar assemblage at an ancient ore deposit allows for the interpretation that the deposit is certainly hypogene in origin. However, further work at Mount Cameroon should focus on proposing a suitable model that incorporates element dissolution, redistribution and precipitation and how this is influenced by the chemical composition of the fumaroles. To date, the chemistry of these fluids remains unknown.

\section{Acknowledgements}

CES and EMS were supported by research grants to EMS that supported the XRD analyses. Further support for field work through the Alexander von Humboldt Foundation (AvH Stiftung, Germany) Cooperation Project between the University of Buea (Cameroon) and the Technical University of Clausthal (Germany) is also acknowledged. This Cooperation Project supported the research works of AV and TA as postgraduate students. This manuscript benefited largely from comprehensive comments by an anonymous reviewer.

\section{Conflicts of Interest}

The authors declare no conflicts of interest regarding the publication of this paper.

\section{References}

[1] Suh, C.E., Ayonghe, S.N. and Njumbe, E.S. (2001) Neotectonic Earth Movement Related to the 1999 Eruption of Cameroon Mountain, West Africa. Episodes, 24, 9-12. 
[2] Suh, C.E., Sparks, R.S.J., Fitton, J.G., Ayonghe, S.N., Annen, C., Nana, R. and Luckman, A. (2003) The 1999 and 2000 Eruptions of Mount Cameroon: Eruption Behaviour and Petrochemistry of Lava. Bulletin of Volcanology, 65, 267-281. https://doi.org/10.1007/s00445-002-0257-7

[3] Deruelle, B., Ngounouno, I. and Demaiffe, D. (2007) The Cameroon Hot Line (CHL): A Unique Example of Active Alkaline Intraplate Structure in Both Oceanic and Continental Lithospheres. Comptes Rendus Geoscience, 339, 589-600. https://doi.org/10.1016/j.crte.2007.07.007

[4] Njome, M.S., Suh, C.E., Sparks, R.S.J., Ayonghe, S.N. and Fitton, J.G. (2008) The Mount Cameroon 1959 Compound Lava Flow Field: Morphology, Petrography and Geochemistry. Swiss Journal of Geoscience, 101, 85-98. https://doi.org/10.1007/s00015-007-1245-x

[5] Suh, C.E., Luhr, J.F. and Njome, M.S. (2008) Olivine-Hosted Glass Inclusions from Scoriae Erupted in 1954-2000 at Mount Cameroon Volcano, West Africa. Journal of Volcanology and Geothermal Research, 169, 1-33. https://doi.org/10.1016/j.jvolgeores.2007.07.004

[6] Suh, C.E., Stansfield, S.A., Sparks, R.S.J., Njome, M.S., Wantim, M.N. and Ernst, G.G.J. (2010) Morphology and Structure of the 1999 Lava Flows at Mount Cameroon Volcano (West Africa) and Their Bearing on the Emplacement Dynamics of Volume-Limited Flows. Geological Magazine, 148, 22-34.

https://doi.org/10.1017/S0016756810000312

[7] Njome, M.S. and de Wit, M.J. (2014) The Cameroon Line: Analysis of an Intraplate Magmatic Province Transecting Both Oceanic and Continental Lithospheres: Constraints, Controversies and Models. Earth Science Reviews, 139, 168-194. https://doi.org/10.1016/j.earscirev.2014.09.003

[8] Ngwa, C.N., Hansteen, T.H., Devey, C.W., Van der Zwan, F.M. and Suh, C.E. (2017) Origin and Evolution of Primitive Melts from the Debunscha Maar, Cameroon: Consequences for Mantle Source Heterogeneity within the Cameroon Volcanic Line. Lithos, 288-289, 326-337. https://doi.org/10.1016/j.lithos.2017.06.028

[9] Atanga, M.B.S., Merve, A.V.D., Shemang, E.M., Kruger, W., Suh, C.E., Njome, M.S. and Asobo, N.E. (2009) Volcanic Ash from the 1999 Eruption of Mount Cameroon Volcano: Characterization and Implication to Health. Journal of the Cameroon Academy of Sciences, 8, 63-70.

[10] Ateba, B., Dorbath, C., Dorbath, L., Ntepe, N., Frogneux, M., Aka, F.T., Hell, J.V., Delmond, J.C. and Manguelle, D. (2009) Eruptive and Earthquake Activities Related to the 2000 Eruption of Mount Cameroon Volcano (West Africa). Journal of Volcanology and Geothermal Research, 179, 206-216. https://doi.org/10.1016/j.jvolgeores.2008.11.021

[11] Atanga, M.B.S., Merve, A.V.D., Njome, M.S., Kruger, W. and Suh, C.E. (2010) Health System Preparedness for Hazards Associated with Mount Cameroon Eruptions: A Case Study of Bakingili Village. International Journal of Mass Emergencies and Disasters, 28, 298-325.

[12] Njome, M.S., Suh, C.E., Chuyong, G. and de Wit, M.J. (2010) Volcanic Risk Perception in Rural Communities along the Slopes of Mount Cameroon, West-Central Africa. Journal of African Earth Science, 58, 608-622. https://doi.org/10.1016/j.jafrearsci.2010.08.007

[13] Del Marmol, M.-A., Fontijn, K., Atanga, M., Njome, S., Mafany, G., Tening, A., Wantim, M.N., Fonge, B., Che, V.B., Festus, A., Ernst, G.G.J., Suh, E., Jacobs, P. and Kervyn, M. (2017) Investigating the Management of Geological Hazards and Risks 
in the Mt Cameroon Area Using Focus Group Discussions. In: Advances in Volcanology, Observing the Volcano World, Springer, New York, 373-394. https://doi.org/10.1007/11157_2017_3

[14] Wantim, M.N., Bonadonna, C., Gregg, C.E., Menoni, S., Frischknecht, C., Kervyn, M. and Ayonghe, S.N. (2018) Forensic Assessment of the 1999 Mount Cameroon Eruption, West-Central Africa. Journal of Volcanology and Geothermal Research, 358, 13-30. https://doi.org/10.1016/j.jvolgeores.2018.06.007

[15] Larocque, A.C.L., Stimac, J.A. and Siebe, C. (1998) Metal-Residence Sites in Lavas and Tuffs from Volcán Popocatépetl, Mexico: Implications for Metal Mobility in the Environment. Environmental Geology, 33, 197-208. https://doi.org/10.1007/s002540050238

[16] Larocque, A.C.L., Stimac, J.A., Siebe, C., Greengrass, K., Chapman, R. and Mejia, S.R. (2008) Deposition of a High-Sulfidation Au Assemblage from a Magmatic Volatile Phase, Volcán Popocatépetl. Mexico. Journal of Volcanology and Geothermal Research, 170, 51-60. https://doi.org/10.1016/j.jvolgeores.2007.09.009

[17] Forero, J., Zuluaga, C. and Mojica, J. (2011) Alteration Related to Hydrothermal Activity of the Nevado Del Ruiz Volcano (NRV), Colombia. Boletín de Geología, 30, 59-67.

[18] Chemtob, S.T. and Rossman, G.R. (2014) Timescales and Mechanisms of Formation of Amorphous Silica Coatings on Fresh Basalts at Kilauea Volcano, Hawaii. Journal of Volcanology and Geothermal Research, 286, 41-54. https://doi.org/10.1016/j.jvolgeores.2014.08.029

[19] Hausrath, E.M. and Tschauner, O. (2013) Natural Fumarolic Alteration of Fluorapaite, Olivine, and Basaltic Glass, and implications for Habitable Environments on Mars. Astrobiology, 13, 1049-1064. https://doi.org/10.1089/ast.2013.0985

[20] MacLean, W.H. and Kranidiotis, P. (1987) Immobile Elements as Monitors of Mass Transfer in Hydrothermal Alteration: Phelps Dodge Massive Sulfide Deposit, Matagami, Quebec. Economic Geology, 82, 951-962. https://doi.org/10.2113/gsecongeo.82.4.951

[21] Wantim, M.N., Kervyn, M., Ernst, G.G.J., del Marmol, M.A., Kervyn, M., Suh, C.E. and Jacobs, P. (2013) Numerical Experiments on the Dynamics of Channelized Lava Flows at Mount Cameroon Volcano with the FLOWGO Thermo-Rheological Model. Journal of Volcanology and Geothermal Research, 253, 35-53. https://doi.org/10.1016/j.jvolgeores.2012.12.003

[22] Wantim, M.N., Suh, C.E., Ernst, G.G.J., Kervyn, M. and Jacobs, P. (2011) Characteristics of the 2000 Fissure Eruption and Lava Flow Fields at Mount Cameroon Volcano, West Africa: A Combined Field Mapping and Remote Sensing Approach. Geological Journal, 46, 344-363. https://doi.org/10.1002/gj.1277

[23] Villemant, B., Komorowski, J.C., Dessert, C., Michel, A., Crispi, O., Hammouya, G., Beauducel, F. and Chabalier, J.B. (2014) Evidence for a New Shallow Magma Intrusion at La Soufrière of Guadeloupe (Lesser Antilles), Insights from Long-Term Geochemical Monitoring of Halogen-Rich Hydrothermal Fluids. Journal of Volcanology and Geothermal Research, 285, 247-277. https://doi.org/10.1016/j.jvolgeores.2014.08.002

[24] Dorn, R.I. (1998) Rock Coatings. Elsevier, Amsterdam, New York, 429 p.

[25] Prinsloo, L.C., Colomban, P., Brink, J.D. and Meiklejohn, I. (2010) A Raman Spectroscopic Study of the Igneous Rocks on Marion Island: A Possible Terrestrial Analogue for the Geology on Mars. Journal of Raman Spectroscopy, 42, 626-632. https://doi.org/10.1002/jrs.2756 
[26] Schiffman, P., Zierenberg, R., Marks, N., Bishop, J.L. and Dyar, M.D. (2006) Acid-Fog Deposition at Kilauea Volcano: A Possible Mechanism for the Formation of Siliceous-Sulfate Rock Coatings on Mars. Geology, 34, 921-924. https://doi.org/10.1130/G22620A.1

[27] Hellmann, R., Daval, D. and Wirth, R. (2013) Formation of Amorphous Silica Surface Layers by Dissolution-Reprecipitation during Chemical Weathering: Implications for $\mathrm{CO}_{2}$ Uptake. Procedia Earth and Planetary Science Letters, 7, 346-349. https://doi.org/10.1016/j.proeps.2013.03.154

[28] Alt, J.C. and Teagle, D.A.H. (2003) Hydrothermal Alteration of Upper Oceanic Crust Formed at Fast-Spreading Ridge: Mineral, Chemical, and Isotopic Evidence from ODP Site 801. Chemical Geology, 201, 191-211. https://doi.org/10.1016/S0009-2541(03)00201-8

[29] Tivey, M.K. (2007) Generation of Seafloor Hydrothermal Vent Fluids and Associated Mineral Deposits. Oceanography, 20, 50-65.

https://doi.org/10.5670/oceanog.2007.80

[30] Carrino, T.A., Crósta, A.P., Toledo, C.L.B., Silva, A.M. and Silva, J.L. (2015) Geology and Hydrothermal Alteration of the Chapi Chiara Prospect and Nearby Targets, Southern Peru, Using ASTER Data and Reflectance Spectroscopy. Economic Geology, 100, 73-90. https://doi.org/10.2113/econgeo.110.1.73

[31] Minitti, M.E., Weitz, C.M., Lane, M.D. and Bishop, J.L. (2007) Morphology, Chemistry and Spectral Properties of Hawaiin Rock Coatings and Implications for Mars. Journal of Geophysical Research, 112, E05015. https://doi.org/10.1029/2006JE002839

[32] Lopez, G.P., Hitzman, M.W. and Nelson, E.P. (2014) Alteration Patterns and Structural Controls of the El Espino IOCG Mining District, Chile. Mineralum Deposita, 49, 235-259. 